\title{
Case Report: Intraocular Gnathostomiasis: Report of a Case and Review of Literature
}

\author{
Gopal S. Pillai, Anil Kumar,* Natasha Radhakrishnan, Jayasree Maniyelil, Tufela Shafi, \\ Kavitha R. Dinesh, and Shamsul Karim \\ Departments of Ophthalmology, Microbiology, and Pathology, Amrita Institute of Medical Sciences, Ponekara, Kochi, Kerala, India
}

\begin{abstract}
Intraocular gnathostomiasis is a rare parasitic infection caused by the third-stage larvae of spiruroid nematode Gnanthostoma spp. seen mostly in tropical and subtropical regions. It is a food-borne zoonosis caused by ingestion of raw or undercooked freshwater fish, amphibians, reptiles, birds, and mammals, all of which are known to harbor advanced third-stage larvae of Gnanthostoma spp. To date, 74 cases of intraocular gnathostomiasis have been reported from 12 different countries. Only four countries have reported more than 10 cases each, and India shares the rare distinction of being one of them, with 14 cases. Surprisingly, not a single case of cutaneous gnanthostomiasis has ever been reported from India. We present one such case of intraocular gnathostomiasis in a 41-year-old male who presented with an actively motile worm attached to the iris, and we review the pertinent literature of all such cases reported from India.
\end{abstract}

\section{INTRODUCTION}

Although Baylisascaris procyonis, Gnathostoma spinigerum, Toxacara cati, T. canis, Acylostoma cannium, Strongyloides stercoralis, Ascaris lumbricoidis, and T. solium cysticerci can cause ocular larva migrans, G. spinigerum is more often associated with a unique unilateral form of ocular larva migrans, where an actively motile parasite can be seen more often in the anterior and less frequently in the posterior segment of the eye. ${ }^{1} G$. spinigerum is the most common Gnathostoma spp. in Asia, but G. hispidum, G. doloresi, and G. nipponicum have also been occasionally reported. High endemicity has been reported in Thailand, Japan, and Mexico, where people have a custom of consuming raw fish dishes. ${ }^{1}$ Consumption of smoked and marinated fishes and crabs is also seen in eastern and northeastern parts of India; therefore, it is not surprising that most of the Indian cases have been reported from this region. We report the first case of intraocular gnathostomiasis from the southern state of Kerala and review all the cases reported from India to discuss the epidemiology.

\section{CASE REPORT}

We present a case of a 41-year-old male who was refereed to us with decrease in vision in the right eye. On examination, the visual acuity in the right eye was $6 / 9$, and the visual acuity in the left eye was 6/6. On examination, he showed a normal looking left eye. The right eye showed mild ciliary congestion and pigments on the endothelium and anterior lens capsule. The anterior chamber had ++ cells and ++ flare. Otherwise, the iris was normal, and the pupil reacted normally. Media was clear, but vitreous had $1+$ cells. The optic disc and macula were abnormal, with infratemporal retinal hemorrhages and areas of vasculitis with a suspicious retinitis anterior to it. Intraocular pressure was $29 \mathrm{mmHg}$ in the right eye.

With a diagnosis of panuveitis with vasculitis and possible retinitis, our first diagnosis was acute retinal necrosis in evolution. We performed a vasculitis workup and took an aque-

*Address correspondence to Anil Kumar, Department of Microbiology, Amrita Institute of Medical Sciences, Amrita Lane, Ponekkara, Kochi, Kerala, India 682041. E-mail: vanilkumar@aims.amrita.edu ous sample for polymerase chain reaction (PCR) for herpes virus. He was started on topical steroids and antiglaucoma agents and asked to report if symptoms worsened. Antivirals were withheld at this point of time, because hard evidence for virus was lacking. No significant evidence of systemic vasculitis or active infection was documented.

The patient returned after 1 week with worsening of symptoms, and on examination, visual acuity had dropped to $6 / 18$ in the right eye. Anterior chamber inflammation had increased to 3+ cells, and there was evidence of posterior synechea. Iris was muddy, and a live worm was seen hooked to the iris. Corneal edema and episcleral hyperemia in the right eye were observed, and surgery for removal of the nematode was recommended. Under peribulbar anesthesia, the eye was clipped, and the cornea was incised at the limbus with a BP knife number 11; the nematode was extracted with forceps and dialler from the anterior eye chamber (Supplemental Videos 1 and 2).

The larva measured $4 \mathrm{~mm}$ in length and $0.5 \mathrm{~mm}$ in width. The head bulb was transparent white and globular that was easily distinguishable from the rest of the body, which was dark black in color with a rounded posterior end (Figure 1). The parasite was sent for histology, and the sections showed four rows of hooklets, lateral spines, pigmented granular material in the intestinal cells, and multinucleated lateral chords (Figures 2-5). Blood smears were negative for microfilaria and eosinophilia, with no history of any recent travel. The patient was advised to take albendazole for 21 days, and he recovered without any sequela.

\section{DISCUSSION}

Of the 12 known species within the genus Gnathostoma, only 4 species have been known to infect humans; G. nipponicum is found in weasels in Japan, G. hispidum is found in pigs in Europe, Asia, and Australia, G. doloresi is found in wild boars, and G. spinigerum is found in wild and domestic cats and dogs in Southeast Asia, China, Japan, and India. ${ }^{1}$ Humans become accidental host when they consume raw or undercooked meat of the definitive host like cats, dogs, and wild animals, second intermediate hosts like brackish water fish, chicken, snails, and frogs, or paratenic hosts like birds. The parasite fails to reach sexual maturity in humans but may remain alive up to 10 years. In the definitive host, the adult worm lives coiled in the 


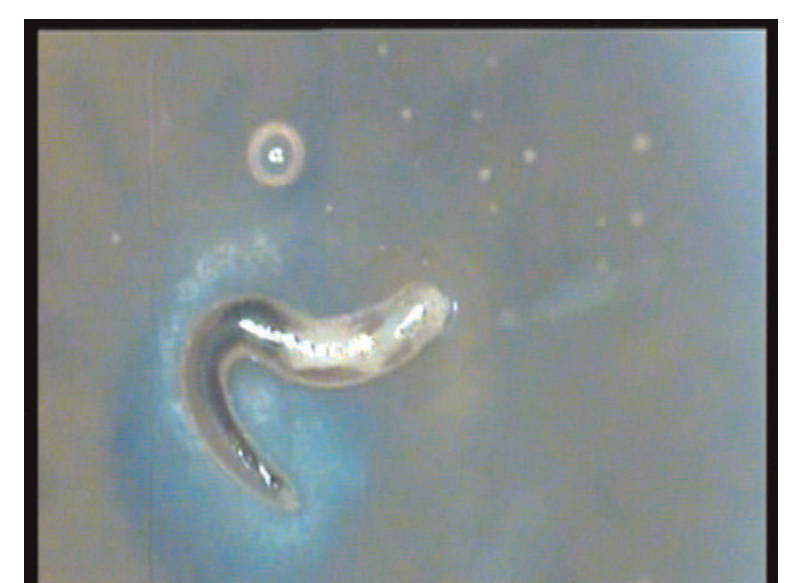

Figure 1. Third-stage larvae of G. spinigerum showing transparent white globular heads are easily distinguishable from the rest of the body, which are black in color with a rounded posterior end.

stomach, producing a tumor-like mass and releasing eggs that are passed in the feces. However, humans can also become the second intermediate host through consumption of water contaminated with copepods infected with second-stage larvae. Another alternative route of infection is by penetration of the skin of food handlers by the third-stage larvae from infected meat. ${ }^{2}$ Cutaneous lesions like migratory panniculitis or serpiginous eruptions caused by the migration of the third-stage larvae are the most common manifestation of this infection, but their onset may be delayed for months and even years. ${ }^{3,4}$ Migration to unexpected sites leads to visceral involvement of the lungs, gastrointestinal tract, genitourinary tract, ear, central nervous system, and eye. Among the various forms of visceral gnathostomiasis, central nervous system infestation causes fatal eosinophilic myeloencephalitis, whereas ocular involvement is rare. ${ }^{5,6}$ The most common manifestation of intraocular gnathostomiasis is anterior uveitis and intraocular parasite, because it mostly localizes itself in the anterior segment of the eye. The other common manifestations are eyelid edema, conjuctival chemosis, hyphema, retinochoroidal, vitreous hemorrhage, and rarely, central retinal artery occlusion leading to blindness. $^{7}$ The portal of entry into the eye may be posterior retina, because intraocular gnathostomiasis has been associ-

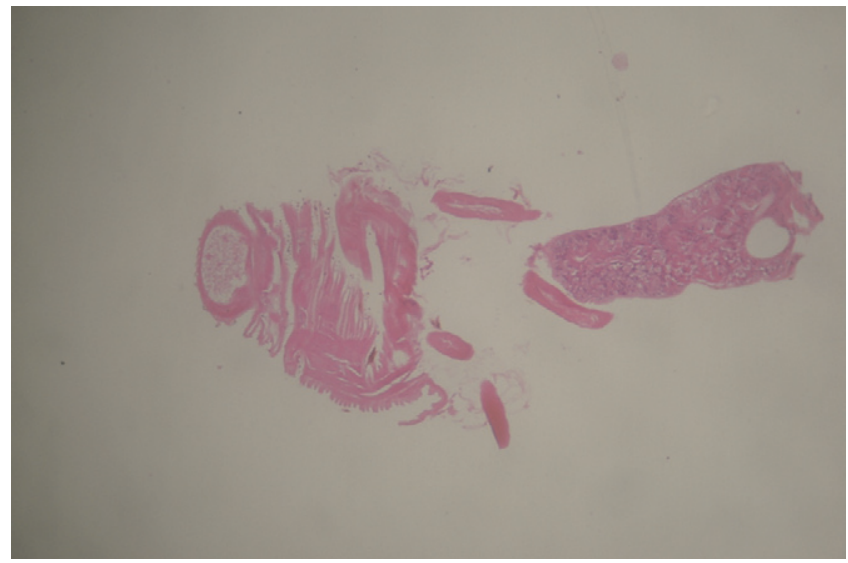

FIGURE 2. Longitudinal section (hematoxylin/eosin). Magnification: $100 \times$

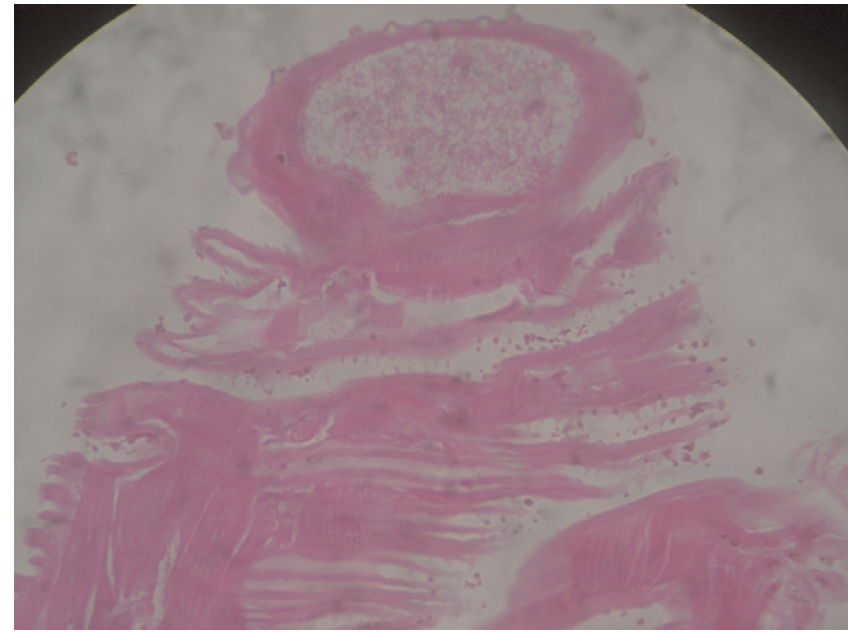

FIGURE 3. Longitudinal section (hematoxylin/eosin) of the anterior end showing four rows of hooklets and lateral spines. Magnification: $400 \times$.

ated with macular scarring, rupture of nasal branch of central retinal artery, or retinal tear with choroidal hemorrhage near the optic disc. ${ }^{8}$

The first case of intraocular gnathostomiasis was reported by Rhitthibaed and Daengsvang ${ }^{9}$ in 1937, and in 1945, Sen and Ghose ${ }^{10}$ reported the third such case from India. Since that time, 74 cases have been reported from around 12 countries, and $83.5 \%$ (61) of cases were either from Asian countries or among immigrants from Asia. ${ }^{7}$ Four countries contributed more than 10 cases each: Japan, Thailand, Mexico, and India. ${ }^{7}$ Unlike the other three countries, in India, consumption of raw or smoked brackish water fish is not widespread. Only the eastern and northeastern Indian states have a custom of consuming smoked, steamed, or marinated brackish water fish and crabs, whereas most tribes of the Mongoloid stock in the states of Mizoram and Nagaland consume dogs as part of their traditional custom. Cutaneous gnathostomiasis, which is the most common manifestation, has been reported from all the endemic countries, with

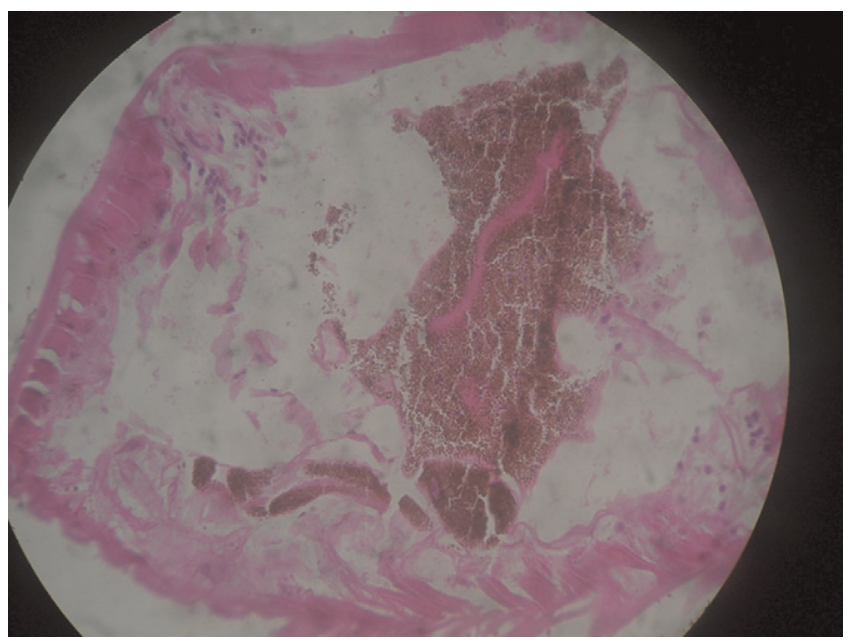

Figure 4. Cross-section showing pigmented granular material in the intestinal cells (hematoxylin/eosin). Magnification: $400 \times$. 


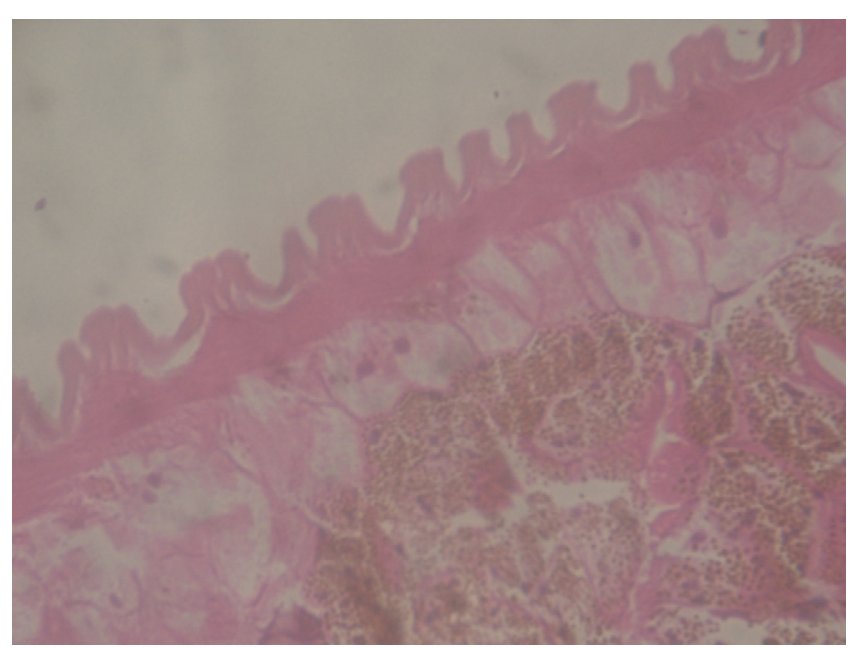

FIGURE 5. Cross-section showing multinuceate lateral chords (hematoxylin/eosin). Magnification: $1000 \times$. the notable exception of India. ${ }^{7}$ This discrepancy may be explained by the fact that the eye is the organ in which the larvae can be actually visualized, and therefore, there are more literature reports of ocular involvement than involvement of other organs. ${ }^{11}$ Another hypothesis is that, in India, the source of infection may be water contaminated with cyclops harboring early third-stage larvae (EL3). Because they are smaller in size compared with the advanced thirdstage larvae (AL3; from fish or other paratenic host), they could easily disseminate through circulation into the eyes. ${ }^{7}$

Clinical and demographic details of 13 cases reported from India are described in Table 1 . We report the first case of intraocular gnathostomiasis from the southern state of Kerala, where the consumption of brackish water fish is considered a delicacy. Kerala is endemic to another intraocular parasite, Dirofilaria spp., and almost all the cases of dirofilariasis were subconjuctival. ${ }^{20}$ Two cases of diffuse unilateral subacute neuroretinitis (DUSN) successfully treated with laser photocoagulation have also been reported from this

TABLE 1

Demographic and clinical characteristics of cases of gnathostomiasis reported from India

\begin{tabular}{|c|c|c|c|c|c|c|}
\hline $\begin{array}{l}\text { Year, province, and part } \\
\text { of the country }\end{array}$ & Age (years)/sex & Site & Eye & Symptoms & Signs & Relevant history \\
\hline 1969, West Bengal, east ${ }^{12}$ & 32/female & $\mathrm{AC}$ & Right & Pain and redness & $\begin{array}{l}\text { Muddy iris, lid swelling, } \\
\text { and hypopyon }\end{array}$ & None \\
\hline 1969, West Bengal, east ${ }^{12}$ & $23 /$ male & $\mathrm{AC}$ & Left & Pain and swelling & $\begin{array}{l}\text { Anterior chamber deep } \\
\text { and visual acuity } \\
\text { hand movement }\end{array}$ & None \\
\hline 1994, West Bengal, east ${ }^{13}$ & 30/female & $\mathrm{AC}$ & Left & Painless loss of vision & $\begin{array}{l}\text { Pan uveitis, vitreous haze, } \\
\text { and holes in iris }\end{array}$ & None \\
\hline 1994, West Bengal, east ${ }^{13}$ & $24 /$ male & $\mathrm{AC}$ & Right & Pain, redness, and photophobia & $\begin{array}{l}\text { Holes in iris, corneal edema, } \\
\text { keratic presipitates, aqueous } \\
\text { flare, posterior synechia, } \\
\text { secondary glaucoma, and } \\
\text { subretinal hemorrhages }\end{array}$ & None \\
\hline 1999, Tamil Nadu, south ${ }^{14}$ & 41/female & $\mathrm{AC}$ & Right & Pain, redness, and lacrymation & $\begin{array}{l}\text { Holes in iris, circumcilliary } \\
\text { congestion, and } \\
\text { posterior synechia }\end{array}$ & Swelling in axilla \\
\hline 2007, Assam, northeast ${ }^{15}$ & 48/female & $\mathrm{PC}$ & Left & Diminished vision and floaters & $\begin{array}{l}\text { Hemorrhage of optic disc and } \\
\text { edema of optic nerve }\end{array}$ & Smoked fish \\
\hline 2004, West Bengal, east ${ }^{8}$ & $50 /$ male & $\mathrm{PC}$ & Right & $\begin{array}{l}\text { Diminished vision, pain, } \\
\text { periocular swelling, and } \\
\text { diminished vision }\end{array}$ & Severe chemosis & None \\
\hline 2007, Assam, northeast ${ }^{16}$ & 32/female & $\mathrm{PC}$ & Left & $\begin{array}{l}\text { Pain, redness, lacrymation, } \\
\text { diminished vision, } \\
\text { and photophobia }\end{array}$ & $\begin{array}{l}\text { Flare in anterior chamber } \\
\text { and sluggish pupillary } \\
\text { reaction }\end{array}$ & $\begin{array}{l}\text { Left-side abdomen } \\
\text { swelling that } \\
\text { migrated to } \\
\text { the face }\end{array}$ \\
\hline 2009, Odihsa, east ${ }^{17}$ & 28/female & $\mathrm{AC}$ & Left & $\begin{array}{l}\text { Swelling, pain, redness, } \\
\text { and lacrymation }\end{array}$ & Iris pierced by the worm & None \\
\hline 1945, West Bengal, east ${ }^{10}$ & $26 /$ male & $\mathrm{AC}$ & Left & $\begin{array}{l}\text { Unable to open eye } \\
\text { because of swollen eyelids }\end{array}$ & $\begin{array}{l}\text { Restricted eye movement, } \\
\text { sluggish pupillary reaction, } \\
\text { gray-pigmented nodule on } \\
\text { iris, and chemosis }\end{array}$ & $\begin{array}{l}\text { Left-sided } \\
\text { headache and } \\
\text { swelling of } \\
\text { the left cheek }\end{array}$ \\
\hline 1999, Pondycherry, south ${ }^{19}$ & 34/female & $\mathrm{AC}$ & Left & $\begin{array}{l}\text { Pain, photophobia, } \\
\text { loss of vision, } \\
\text { and lid edema }\end{array}$ & $\begin{array}{l}\text { Keratic presipitates, holes in } \\
\text { iris, circumcilliary } \\
\text { congestion, and } \\
\text { posterior synechia }\end{array}$ & $\begin{array}{l}\text { Pain, photophobia, } \\
\text { loss of vision, } \\
\text { and lid edema }\end{array}$ \\
\hline 2005, Tamil Nadu, south ${ }^{18}$ & 39/Female & $\mathrm{AC}$ & Left & $\begin{array}{l}\text { Acute painful unilateral loss of } \\
\text { vision }\end{array}$ & $\begin{array}{l}\text { Circumcilliary congestion, full } \\
\text { thickness iris holes, pigment } \\
\text { deposited on the anterior } \\
\text { surface of cornea, viterous } \\
\text { hemorrhage, macular } \\
\text { oedema, retinal hemorrhage }\end{array}$ & $\begin{array}{l}\text { Bathing in the } \\
\text { river }\end{array}$ \\
\hline $\begin{array}{l}\text { 2010, Kerala, south } \\
\text { (present case) }\end{array}$ & 43/Male & $\mathrm{AC}$ & Right & Diminished vision & $\begin{array}{l}\text { Muddy iris, posterior synechia, } \\
\text { corneal oedema, retinal } \\
\text { haemorrhages }\end{array}$ & None \\
\hline
\end{tabular}


region. $^{21,22}$ Unfortunately, the parasites in both these cases could not be identified, because they disintegrated under the effect of the laser. Because of the avascularity of the anterior chamber of the eye, eosinophilia, which is the hallmark of parasitic infections, is evidently absent and usually mild if at all present. ${ }^{4}$ High-dose albendazole, given for 3 weeks, has been used as specific chemotherapy for treatment of patients with gnathostomiasis. ${ }^{23}$ With the ever-increasing reports of intraocular gnathostomiasis from India, it has become imperative that the clinicians become familiar with this disease; therefore, diagnosis is not missed or delayed, avoiding potentially serious complications.

Received November 18, 2011. Accepted for publication January 13, 2012.

Note: Supplemental videos appear online at www.ajtmh.org/content/ 86/4/620/suppl/DC1.

Acknowledgments: The American Committee on Clinical Tropical Medicine and Travelers' Health (ACCTMTH) assisted with publication expenses.

Authors' addresses: Gopal S. Pillai, Natasha Radhakrishnan, and Tufela Shafi, Department of Ophthalmology, Amrita Institute of Medical Sciences, Ponekkara, Kochi, Kerala, India, E-mails: gopalspillai@gmail.com, natashar@aims.amrita.edu, and tufelashafi@aims.amrita.edu. Anil Kumar, Kavitha R. Dinesh, and Shamsul Karim, Department of Microbiology, Amrita Institute of Medical Sciences, Ponekkara, Kochi, Kerala, Inida, E-mails: vanilkumar@aims.amrita.edu, kavitharadhakrishnan@ aims.amrita.edu, and shamsulkarim@aims.amrita.edu. Jayasree Maniyelil Department of Pathology, Amrita Institute of Medical Sciences, Ponekkara, Kochi, Kerala, India, E-mail: shajiaims@gmail.com.

\section{REFERENCES}

1. Herman JS, Chiodini PL, 2009. Gnathostomiasis, another emerging imported disease. Clin Microbiol Rev 22: 484-492.

2. Daengsvang S, 1981. Gnathostomiasis in southeast Asia. Southeast Asian J Trop Med Public Health 12: 319-332.

3. McCarthy J, Moore TA, 2000. Emerging helminth zoonoses. Int J Parasitol 30: 1351-1360.

4. Rusnak JM, Lucey DR, 1993. Clinical gnathostomiasis: case report and review of the English-language literature. Clin Infect Dis 16: 33-50.

5. Boongird P, Phuapradit P, Siridej N, Chirachariyavej T, Chuahirun S, Vejjajiva A, 1977. Neurological manifestations of gnathostomiasis. J Neurol Sci 31: 279-291.
6. Punyagupta S, Bunnag T, Juttijudata P, 1990. Eosinophilic meningitis in Thailand. Clinical and epidemiological characteristics of 162 patients with myeloencephalitis probably caused by Gnathostoma spinigerum. J Neurol Sci 96: 241-256.

7. Nawa Y, Katchanov J, Yoshikawa M, Rojekittikhun W, Dekumyoy P, Kusolusuk T, Wattanakulpanich D, 2010. Ocular gnathostomiasis: a comprehensive review. J Trop Med Parasitol 33: 77-86.

8. Basak SK, Sinha TK, Bhattacharya D, Hazra TK, Parikh S, 2004. Intravitreal live Gnathostoma spinigerum. Indian J Ophthalmol 52: $57-58$

9. Rhitthibaed C, Daengsvang S, 1937. A case of blindness caused by Gnathstoma spinigerum. J Med Assoc Thai 19: 840-845.

10. Sen K, Ghose N, 1945. Ocular gnathostomiasis. Br J Ophthalmol 29: 618-626.

11. Guitierrez Y, 2000. Diagnostic Pathology of Parasitic Infections with Clinical Correlations, 2nd ed. Oxford, United Kingdom: Oxford University Press.

12. Seal GN, Gupta AK, Das MK, 1969. Intra-ocular gnathostomiasis. Indian J Ophthalmol 17: 109-113.

13. Biswas J, Gopal L, Sharma T, Badrinath SS, 1994. Intraocular Gnathostoma spinigerum. Clinicopathologic study of two cases with review of literature. Retina 14: 438-444.

14. Kannan KA, Vasantha K, Venugopal M, 1999. Intraocular gnathostomiasis. Indian J Ophthalmol 47: 252-253.

15. Bhattacharjee H, Das D, Medhi J, 2007. Intravitreal gnathostomiasis and review of literature. Retina 27: 67-73.

16. Barua P, Hazarika NK, Barua N, Barua CK, Choudhury B, 2007. Gnathostomiasis of the anterior chamber. Indian J Med Microbiol 25: 276-278.

17. Tiwari S, Chayani N, Rautaraya B, 2009. Intraocular Gnathostoma spinigerum: a case report. Cases J 22: 9370-9372.

18. Bhende M, Biswas J, Gopal L, 2005. Ultrasound biomicroscopy in the diagnosis and management of intraocular gnathostomiasis. Am J Ophthalmol 140: 140-142.

19. Rao VA, Pravin T, Parija SC, 1999. Intracameral gnathostomiasins: a first case report from Pondicherry. J Commun Dis 31: 197-198.

20. Sekhar HS, Srinivasa H, Batru RR, Mathai E, Shariff S, Macaden RS, 2000. Human ocular dirofilariasis in Kerala Southern India. Indian J Pathol Microbiol 43: 77-79.

21. Natesh S, K H, Nair U, Nair K, 2010. Subretinal worm and repeat laser photocoagulation. Middle East Afr J Ophthalmol 17: $183-185$.

22. Ittyerah TP, 1990. Nematode in the retina. Indian J Ophthalmol 38: $178-179$.

23. Nontasut P, Claesson BA, Dekumyoy P, Pakdee W, Chullawichit S, 2005. Double-dose ivermetcin vs albendazole for treatment of gnathostomiasis. Southeast Asian J Trop Med Public Health 36: $650-652$. 